\title{
THE FAMILY INNOVATOR'S DILEMMA: HOW FAMILY INFLUENCE AFFECTS THE ADOPTION OF DISCONTINUOUS TECHNOLOGIES BY INCUMBENT FIRMS
}

\author{
ANDREAS KÖNIG \\ University of Erlangen-Nuremberg \\ NADINE KAMMERLANDER \\ University of St. Gallen and Otto-Friedrich-University of Bamberg \\ ALBRECHT ENDERS \\ IMD, Lausanne
}

\begin{abstract}
We integrate research on family business and discontinuous change to better explain why incumbents vary in when and how they adopt discontinuous technologies. Family influence induces companies to strive for continuity, command, community, and connections and, thus, alters the mix of constraints under which firms operate. Consequently, family influence weakens several of the inertial forces described in the discontinuous change literature, particularly the level of formalization, dependence on external capital providers, and political resistance. However, it also aggravates critical sources of organizational paralysis, specifically emotional ties to existing assets and the rigidity of mental models. We aggregate these seemingly contradictory effects to show that, overall, discontinuous change conflicts with essential goals and values of the family system, and, therefore, family influence entails fundamentally different dilemmas than those described in extant research. In turn, although highly family-influenced companies recognize discontinuous technologies later than their less family-influenced counterparts, they implement adoption decisions more quickly and with more stamina. Moreover, family influence reduces adoption aggressiveness and flexibility. We discuss important implications of our research for conversations on discontinuous change as well as for the debate on the advantages and disadvantages of family influence in firms.
\end{abstract}

Few questions in management and organization research have attracted more scholarly attention than the question of when and how established organizations, known as incumbents, adopt discontinuous technologies (Chesbrough, 2001; Hill \& Rothaermel, 2003). Most authors have highlighted the predisposition of incumbent firms to resist "strategic renewal outside the frame of current strategy" (Huff, Huff, \& Thomas, 1992: 56) and the resulting tendency to adopt nonparadigmatic innovations late, timidly, and

We gratefully acknowledge helpful comments from Margaret Cording, Angela Fehn, Harald Hungenberg, Björn Ivens, Devereaux Jennings, Allison Pearson, Tina Pedersen, Manisha Singal, Howard Yu, Thomas Zellweger, and participants at the 2011 Academy of Management annual meeting in San Antonio. We also express our appreciation to former associate editor Adelaide Wilcox King and three anonymous reviewers for their valuable input and suggestions. rigidly (Christensen, 1997). These scholars have built on multiple theories to reveal various factors that explain such inertial responses, including high levels of formalization (Hannan \& Freeman, 1984; Levitt \& March, 1988), dependence on external capital providers (Christensen \& Bower, 1996), political resistance (Tushman, Newman, \& Romanelli, 1986), emotional ties to existing assets (Burgelman \& Grove, 1996), and rigid mental models (Tripsas \& Gavetti, 2000).

Other researchers have challenged the notion that incumbent inertia is inevitable and have shown that established organizations vary, often significantly, in their adoption of discontinuous technologies (König, Schulte, \& Enders, 2012; Mitchell, 1989). Such scholars have begun to uncover factors that might cause deviances from the standard pattern of inertia by exploring, for instance, the effects of structural decou- 
pling (Tushman \& O'Reilly, 1996), the preferences of securities analysts (Benner, 2007), and executive narcissism (Gerstner, König, Enders, \& Hambrick, in press).

Although research on variation in organizations' responses to discontinuous innovation has provided a wealth of insights, almost no attention has been devoted to examining how the social contexts of major shareholders, particularly families, determine organizational adaptation to such breakthroughs. In fact, even though studies in the inertia literature include companies that are influenced by family owners, a key question has not yet been addressed: How does the degree to which incumbents are influenced by family owners affect when and how those organizations adopt discontinuous technologies?

This research gap is remarkable not only because the majority of businesses-including some of the largest corporations-are substantially influenced by formilies (Anderson \& Reeb, 2003) but also because owners and investors in general (Benner, 2007), and family owners in particular, play important roles in shaping the strategic activities of firms (Fiss \& Zajac, 2004). Moreover, family-influenced businesses are embedded in an idiosyncratic social system that engenders significant behavioral differences between highly family-influenced and less or non-family-influenced firms (Miller, Le BretonMiller, \& Lester, 2010).

In this article we bridge this gap by integrating two pivotal yet previously disconnected streams of management science: the literature on organizational adaptation to discontinuous changes and family business research. We proceed in three steps. First, we build on these two streams of literature to specify our dependent and independent constructs. Discontinuous change research (Gilbert, 2005) guides us to focus on three dimensions of technology adoption: speed, resource commitment (including aggressiveness and stamina), and flexibility of adoption routines. Family business research directs us to specify family influence as the extent of overlap between the family system and the business system in a firm (Habbershon \& Williams, 1999; Tagiuri \& Davis, 1996). This overlap is reflected in decision makers' efforts to achieve continuity, command, community, and connections (the "Four Cs"; Miller \& Le BretonMiller, 2005). Second, we develop propositions on how varying levels of family influence affect five pivotal determinants of organizational adoption of discontinuous technologies cited in the literature (Hill \& Rothaermel, 2003). These propositions lead to an apparently equivocal picture of the link between family influence and discontinuous technology adoption. Third, we resolve these prima facie contradictions by exploring the interactions of the various consequences of family influence and by syllogizing a coherent model of how formily influence affects the speed, aggressiveness, stamina, and flexibility of incumbent adoption of discontinuous technologies.

Our key contribution to the discontinuous change literature is the demonstration that family influence leads to shifts in organizational constraints, ultimately causing innovators in family-influenced companies to face fundamentally different dilemmas than those previously described (Burgelman \& Grove, 1996; Christensen, 1997). Family influence frees companies from the formalized, short-term-oriented "checks and balances" (Carney, 2005: 252) of capital markets, which have been highlighted in the extant literature as a major cause of inertia in response to discontinuous change (Benner, 2007). At the same time, family influence binds companies to the noneconomic values and preferences that are essential to family systems (Chua, Chrisman, \& Sharma, 1999). As we argue, these differences that family influence injects into the business system significantly affect when and how firms adopt discontinuous innovations and, thus, provide a new explanation for why incumbent firms, contrary to the prevailing paradigm, differ in their responses to discontinuous change.

We also contribute to family business research. In this field the reactions of familyinfluenced businesses to change have increasingly been the subject of scholarly work (Hatum, Pettigrew, \& Michelini, 2010; Zahra, 2010), but the topic of discontinuous change has largely been neglected. Family business scholars have also explored whether fomily influence, in general, constitutes a benefit or a burden, but with inconsistent results (O'Boyle, Pollack, \& Rutherford, 2012; Zahra, Hayton, Neubaum, Dibrell, \& Craig, 2008). Our more granular, context-specific analysis could provide a basis to reconcile these contradictions and thereby inform managers at- 
tempting to navigate organizations through times of technological turmoil.

\section{ADOPTION OF DISCONTINUOUS TECHNOLOGIES BY INCUMBENT FIRMS}

Discontinuous technologies are novel concepts of creating and capturing value "that depart dramatically from the norm of continuous incremental innovation" (Anderson \& Tushman, 1990: 606) and from the traditional innovation trajectory (Christensen \& Bower, 1996; König et al., 2012). Often-studied examples of discontinuous technologies include digital imaging (Tripsas \& Gavetti, 2000), biotechnology (Kaplan, Murray, \& Henderson, 2003), and online news (Gilbert, 2005). These innovations contradict the dominant mindset in an industry, render existing organizational structures and processes obsolete, and decrease the value of existing knowledge bases (Abernathy \& Clark, 1985). Furthermore, discontinuous technologies are highly ambiguous "as to their commercial potential" (Hill \& Rothaermel, 2003: 258). Consequently, determining adequate responses to such radical shifts may be challenging for incumbent firms.

In the spirit of most discontinuous change research, we focus on variance in when and how incumbents adopt discontinuous innovations to "supplement or replace current domains" (Ford \& Baucus, 1987: 372). In earlier research scholars specifically highlighted the temporal dimension of incumbents' adoption of discontinuous technologies by denoting that established players typically enter discontinuous technological domains relatively later than new entrants (Miller \& Friesen, 1980; Szymanski, Troy, \& Bharadwaj, 1995). Our theorizing builds on this literature and investigates speed of adoption, which denotes the swiftness with which organizations (1) recognize a discontinuous technology and interpret it as a relevant strategic issue (Kaplan et al., 2003; Ocasio, 1997), (2) decide to adopt it and how to do so (Christensen, 1997), and (3) implement the adoption decision by ultimately launching a new product based on the discontinuous technology (Lieberman \& Montgomery, 1988).

To answer the question of how established firms adopt discontinuous technologies, we borrow from Gilbert's (2005) differentiation between two distinct aspects of discontinuous technology adoption: resource commitment and routines of implementation. With regard to resource commitment, ${ }^{1}$ Gilbert (2005) observes that incumbents vary in their ability or willingness to allocate resources to the development and commercialization of a discontinuous technology in two respects. First, these companies show different levels of aggressiveness of technology adoption, which we define as the amount of resources a company commits on an annual basis to the exploration of a discontinuous technology (Bower, 1970; Christensen \& Bower, 1996; Gilbert \& Newbery, 1984). Adoption aggressiveness is a focal variable in the context of our study because the impetus of resource commitment to a discontinuous change can determine competitive advantages in both the short run and the long run. For instance, in the years after 1996, Amazon gained significant advantages over physical book retailers because it invested aggressively in the advancement of online retailing (Christensen \& Raynor, 2003).

Second, incumbents vary in their adoption stamina, which we use to denote the length of time over which an established organization commits a significant amount of resources to the development and commercialization of a discontinuous technology. We include adoption stamina in our model because the notion is fre-

\footnotetext{
${ }^{1}$ We assume the following: aggressiveness $(A(y)$ : the amount of resources committed in year $y$ ) and stamina $\left(S=y_{\text {EndofCommitment }}-y_{\text {StartofCommitment }}=\Delta y\right.$ : the number of years the company invests in the discontinuous technology) are two distinct dimensions of resource commitment that, in combination, determine the total amount of resources, $R$, a company invests over the years in the exploration of the discontinuous technology: $R=\Sigma A\left(y_{i}\right)$. In the simplest case of constant aggressiveness $A(y)=A$ and assuming $S$ $>0$, this sum becomes $R=\Sigma A\left(y_{i}\right) \approx A S$. We build our theory on $A(y)$ and $S$-assuming that $A(y) \neq A(y, S)$-since prior literature (e.g., Gilbert, 2005) implies that it is insufficient to solely theorize on the total amount of resources, $R$, because the specific nature of discontinuous technologies (e.g., they typically emerge over an extended period of time) requires a discussion of the temporal distribution of the resource commitment. The theoretical cornerstones of the theories we build on do not provide us with any reason to assume that the organizational temporal patterns (as opposed to $A$ ) of resource commitment differ dependent on family influence. We thus assume that for two organizations, Alpha and Beta, the following equation holds true: if $A_{\text {Alpha }}\left(y_{i}\right)<A_{\text {Beta }}\left(y_{i}\right)$, for any year $y_{i}$ in which $A_{\text {Alpha }}\left(y_{i}\right) \neq 0$ and $A_{\text {Beta }}\left(y_{i}\right) \neq 0$, then $A_{\text {Alpha }}\left(y_{j}\right)<A_{\text {Beta }}\left(y_{j}\right)$ for all $y_{j} \in\left[\max \left\{y_{\text {StartofCommitment, }}\right.\right.$ Alpha, $\left.Y_{\text {StartofCommitment, Beta }}\right\} ; \min \left\{Y_{\text {EndofCommitment, Alpha; }}\right.$ $\left.Y_{\text {EndofCommitment, Beta }}\right\}$.
} 
quently, although only implicitly, referred to in discontinuous change research (Christensen, 1997) and the related corporate venturing literature (Block \& MacMillan, 1985). Such studies argue that, in addition to a certain amount of adoption aggressiveness, the successful adoption of discontinuous technologies requires continued investments of resources over time. The underlying premise is that early attempts to use a discontinuous technology are likely to experience setbacks and require resource-intensive readjustments (Anderson \& Tushman, 1990; Gilbert \& Bower, 2002).

With regard to the routines of discontinuous technology adoption, Gilbert observes that incumbents often fail "to change the organizational processes that use... resource investments" (2005: 741). Newspaper organizations, for instance, aggressively invested in online platforms around the turn of the century. However, most of them merely copied their print content onto their websites rather than developing business models that fit the needs and habits of online users. In our hypothesizing we adhere to Gilbert (2005) and use the inversed term adoption flexibility to capture the degree to which organizations reconfigure internal processes, systems, and structures when implementing discontinuous technologies.

\section{FAMILY INFLUENCE}

Research on family businesses has long emphasized that the behavior of firms influenced by families differs from the behavior of other firms (e.g., Chua et al., 1999; Habbershon \& Williams, 1999). In our theorizing we adopt a system view of family businesses (Distelberg \& Sorenson, 2009; Habbershon, Williams, \& MacMillan, 2003; Tagiuri \& Davis, 1996) to define family influence (Sirmon, Arregle, Hitt, \& Webb, 2008) as the overlap between the "family system" and the "business system" in a profit-seeking organization. ${ }^{2}$ The family system is formed by both

\footnotetext{
${ }^{2}$ When attempting to describe the essence of family businesses, researchers have used a variety of terms that are similar but not identical to family influence, such as family involvement (Chua et al., 1999), family control (Mishra \& McConaughy, 1999), and familiness (Habbershon \& Williams, 1999). We adhere to "fomily influence" because it best reflects the active role that family members take in shaping the behavior of an organization (in contrast to mere "involve-
}

the individual members of one or a few families who share common goals and resources and their interactions, whereas the business system is formed by "the interdependence and interactions of [a firm's employees] within their business environment" (Distelberg \& Sorenson, 2009: 67). The more a company's sensemaking, decision making, and actions are affected by the attributes, interests, values, and cultures of one or a few fomilies, the greater the overlap between the fomily system and the business system (Stafford, Duncan, Dane, \& Winter, 1999).

The fomily system influences the business system through formal and informal mechanisms. Formal mechanisms include fomily ownership and family involvement in board activities and/or management; they are necessary, albeit not sufficient, for family influence (Chua et al., 1999). Informal mechanisms comprise, for instance, language and narratives that become shared by organizational members over time (Sirmon \& Hitt, 2003), as well as idiosyncratic approaches to conflict resolution (Astrachan, Klein, \& Smyrnios, 2002). Informal mechanisms are important because they help to align the values, goals, and identity of a family with those of the business, thereby triggering the development of a "family business culture" (Astrachan et al., 2002: 45).

Given that formal and informal mechanisms can lead to varying levels of overlap between the family and the business systems-from no overlap to full intersection-our definition implies that family influence is a continuous dimension, ranging from low to high, along which all companies can be arrayed. This notion is crucial to our theorizing for it allows us to differentiate among various levels of family influence within family-owned businesses and also to include non-family-owned businesses, thereby avoiding the oversimplistic dichotomous differentiation between "family firms" and "nonfamily firms" (Asstrachan et al., 2002). In addition, our conceptualization of family influence provides a broad yet granular foundation for our theorizing since it focuses not only on the components of a family firm, such as the percentage of ownership held by one family, but also on the

ment"), while it simultaneously denotes the intangible aspects stemming from the overlap of the family and the business systems, such as family traditions, culture, and identification (in contrast to "family control"). 
very "essence" of family influence (Chua et al., 1999: 19)—the formily's common vision, its desire to pass on the firm to future generations, and its commitment to the business.

A fundamental tenet of family business theory is that family influence engenders idiosyncratic firm characteristics and preferences, including noneconomic values and goals (e.g., Chrisman, Chua, \& Kellermanns, 2009; Habbershon \& Williams, 1999), such as the preservation and enhancement of socioeconomical wealth (e.g., Chrisman et al., 2009; Gómez-Mejía, Takács Haynes, Núñez-Nickel, Jacobson, \& MoyanoFuentes, 2007; Habbershon \& Williams, 1999; Zellweger, Kellermanns, Chrisman, \& Chua, 2012). Among the various taxonomies that family business researchers have developed to systematize manifestations of family influence, Miller and Le Breton-Miller's (2005) Four Cs framework has been particularly well received (Chrisman, Kellermanns, Chan, \& Liano, 2010), arguably because it is holistic and corroborated by a rich body of theoretical and empirical research. The Four Cs framework describes four inherent characteristics of family-influenced businesses: continuity, command, community, and connections.

Continuity refers to the observation that, compared to their less fomily-influenced counterparts, highly family-influenced businesses tend to strive for more longevity since their organizational leaders wish to transfer their businesses to the next generation (Miller et al., 2010) and to keep wealth in the family (Gómez-Mejía et al., 2007).

Command denotes the link between family influence and the greater decision-making authority and autonomy of the dominant coalition (Corney, 2005). High levels of command result from the intertwining of ownership and control within family-influenced firms and from the above-average independence of family owners from external stakeholders, especially public shareholders (Miller \& Le Breton-Miller, 2005).

Community refers to the number and intensity of relationships among employees, both within and across hierarchical boundaries (Miller \& Le Breton-Miller, 2005). In an archetypal family business, employees constitute a "pseudofomily" (Tan \& Fock, 2001: 128), which typically attracts employees who value long-lasting social relationships (Lansberg, 1999). Community also refers to the observation that decision makers in highly fomily-influenced businesses typ- ically show a heightened sense of responsibility toward their employees and tend to care more for other organizational members' well-being than decision makers in less family-influenced enterprises (Miller \& Le Breton-Miller, 2005).

Finally, connections captures the notion that highly family-influenced companies typically establish profound and stable relationships with their stakeholders, including their suppliers and complementors (Miller \& Le BretonMiller, 2005). Such ties arise because fomilies view interconnectedness and personal relationships as defining elements of their identities (Gómez-Mejía, Núñez-Nickel, \& Gutierrez, 2001).

A key premise of our research is that continuity, command, community, and connections are reflective, covariant indicators of family influence. In other words, we assume that a marginal increase in family influence entails a marginal increase in all four domains, although this increase is not necessarily equally distributed. An important boundary condition of our model is that it refers to medium-size and large companies. This premise is reasonable because the organizational phenomenon of inertia is typically described for larger, formalized businesses with multilevel resource allocation processes (Bower, 1970).

\section{FAMILY INFLUENCE AND DETERMINANTS OF THE ADOPTION OF DISCONTINUOUS TECHNOLOGIES}

The goal of our theorizing is to develop a comprehensive model of how variance in formily influence, reflected in the Four Cs, affects when and how established companies adopt discontinuous technologies. As illustrated in Figure 1, we proceed in two steps. First, we hypothesize about how family influence affects five important barriers to the adoption of discontinuous technologies by incumbent firms. These barriers-formalization, resource dependence, political resistance, emotional ties to existing assets, and rigid mental models-have been highlighted in literature reviews summarizing the abundant amount of research on organizational adaptation to nonparadigmatic technological shifts (e.g., Ahuja, Lampert, \& Tandon, 2008; Hill \& Rothaermel, 2003; Sydow, Schreyögg, \& Koch, 2009). As the resulting propositions (Propositions 1 through 5) show, family influence alleviates some of these barriers while simultaneously ag- 
FIGURE 1

A Model of the Effect of Family Influence on the Adoption of Discontinuous Technologies by Incumbent Firms

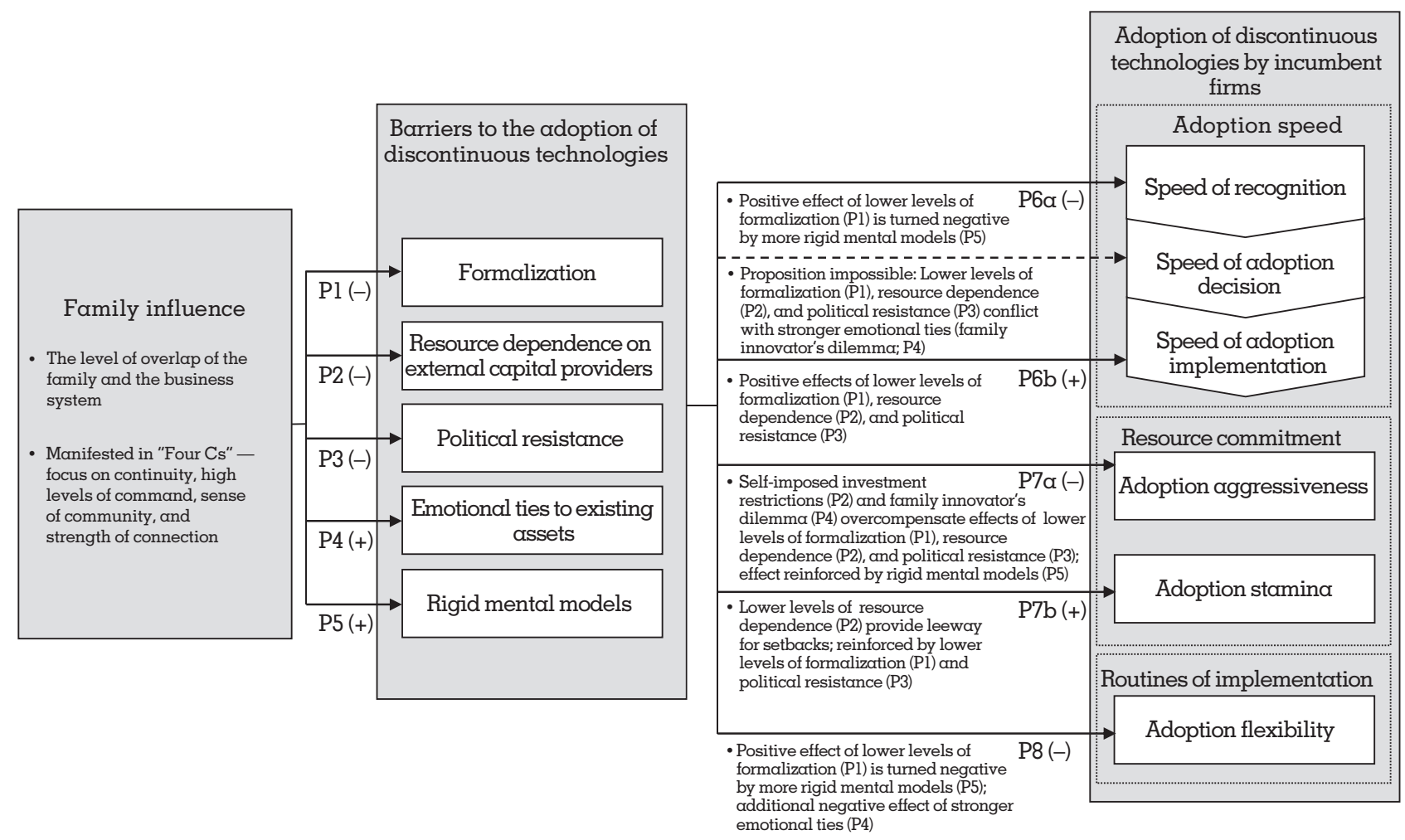

Note: Propositions 6 through 8 illustrate the effects of family influence on the adoption of discontinuous technologies by incumbent firms that are mediated by the (interactions of) the five barriers to the adoption of discontinuous technologies.

gravating others. In a second step we resolve this granular yet puzzling picture by logically connecting the underlying mechanisms and syllogizing Propositions 6 through 8, which formalize how family influence affects the speed of adoption, the aggressiveness and stamina of adoption, and the flexibility of adoption routines.

\section{Family Influence and Formalization}

In the context of this study, formalization refers to the extent to which a given organization has standardized and stabilized its processes of screening for, interpreting, and reacting to changes in the environment (Arrow, 1974; Hannan \& Freeman, 1977; Thomas, Clark, \& Gioia, 1993). As suggested in population ecology and organizational learning theory, formalization is imperative for the success of incumbents in un- disturbed environments (Hannan \& Freeman, 1984; Levitt \& March, 1988). However, high levels of formalization turn into a source of "structural inertia" when discontinuous technologies emerge (Hannon \& Freeman, 1984: 151). In particular, the formalization of screening and interpretation processes induces firms to myopically overlook and underrate discontinuous innovations (Danneels, 2002). Formalization also imposes "ostensive" (Feldman \& Pentland, 2003: 94) bureaucratic elements on organizational structures that slow decision making and constrict the amount of agency available for actors to "perform" routines in a path-divergent manner.

We build on the family business literature to argue that variations in family influence entail changes in the level of organizational formalization. The continuity facet of family influencethe family's inherent focus on transgenerational wealth creation-manifests itself in a focus on 
long-term, rather than short-term, performance targets (Miller \& Le Breton-Miller, 2005). Organizational research suggests that a preference for long-term performance criteria frees companies from a static focus on "local refinements" (Farjoun, 2010: 204), because, in such cases, opportunities are not measured against precise and quantified short-term outcomes but against "softer," more tacit long-term performance parameters. Thus, the long-term focus induced by family influence creates leeway for organizational members to engage in grounded, nonformalized screening and the exploration of a broad set of new opportunities, even if those opportunities involve variability and risk.

The continuity facet of family influence and the associated focus of command in a dominant center are also likely to decrease the levels of organizational formalization. Family-influenced firms strive to maintain control and independence (Gómez-Mejía et al., 2007). The resulting principal-agent unity (Chua et al., 1999) releases actors in highly family-influenced businesses "from the ... calculative or instrumental rationality ... imposed by capital market institutions and internal checks and balances," at least to a certain extent (Corney, 2005: 252, 255). As such, family influence extends actors' agency in the resource allocation process, which allows them to "pursue opportunities that can only be rationalized by particularistic or intuitive [and thus informal] criteria" (Carney, 2005: 260).

Furthermore, the heightened role of community that comes with family influence is largely incompatible with high levels of formalization. As a result of the family system's striving for community, relations in a highly family-influenced business are characterized by a heightened sense of sentiment and emotion (GómezMejía et al., 2001). By definition, emotional social ties are less formalized than more rational relational contracts (Sirmon \& Hitt, 2003). This diminishing effect of community on formalization is reinforced by the more trust-based, rather than contract-based, external connections that family-influenced businesses develop relative to those commonly observed in managerial forms of governance (Carney, 2005; Miller, Steier, \& Le Breton-Miller, 2003; Pearson, Carr, \& Shaw, 2008).

Proposition 1: Ceteris paribus, the stronger the family influence in a firm, the lower the level of formalization in that firm.

\section{Family Influence and Resource Dependence on External Capital Providers}

Resource dependence theory states that decisions in a company are constrained by the organization's dependence on external providers of resources (Christensen \& Bower, 1996; Pfeffer \& Salancik, 1978). In this vein, disruptive innovation theory (Christensen \& Raynor, 2003) highlights the role of external capital providers, who typically require quick, predictable, and significant returns as well as substantial market sizes to fund innovations (Benner, 2007; Christensen, 1997). However, these criteria typically are not met by discontinuous technologies when they emerge (Christensen \& Bower, 1996). Thus, as a consequence of resource dependence, companies face what Christensen (1997) calls the "innovator's dilemma," in which managers at various levels of established organizations have strong incentives to fund continuous innovations instead of discontinuous innovations, even though doing so imperils the long-term future of their organizations.

At the heart of formily business research lies the notion that dependence on external capital decreases as family influence increases (Arregle, Hitt, Sirmon, \& Very, 2007) and that the "particularistic" (Corney, 2005) decision-making processes of family-influenced firms give less priority to the criteria that are important to most external capital providers, especially quick and predictable returns and growth. Firm owners are reluctant to dilute ownership by honding out shares to external capital providers (Carney, 2005; Sirmon \& Hitt, 2003) because they strive for continuity and wish to maintain family control over time by passing their businesses on to future generations (Gómez-Mejía et al., 2007). Family owners' desire to maintain command over their own businesses has a similar effect since it induces them to limit their debt and their accumulation of public equity when investing in strategic initiatives (Gómez-Mejía et al., 2001; Mishra \& McConaughy, 1999; Schulze, Lubatkin, \& Dino, 2003).

Proposition 2: Ceteris paribus, the stronger the family influence in a firm, the lower that firm's level of resource 
dependence on external providers of capital.

\section{Family Influence and Political Resistance}

A third focal inhibitor of organizational adoption is rooted in the fact that the adoption of discontinuous technologies disturbs political equilibria in organizations (Hannan \& Freeman, 1977). As theory of power (Pfeffer, 1992) suggests, implementing such changes is not equally beneficial for all organizational members. Consequently, those managers who anticipate being negatively affected tend to break the "truce" among the various coalitions within the organization (Cyert \& March, 1963) and to engage in political resistance, which refers to all measures organizational members can take to undermine and oppose changes in the status quo (Lüscher \& Lewis, 2008). In turn, political resistance has been depicted as delaying decision making and interpretation and thwarting the momentum behind technological transformation (Kotter, 2007).

We posit that the disposition of organizational members to politically oppose discontinuous change and the ability of executives to overcome such antagonism differ depending on the level of formily influence. If family-influenced firms aim to ensure the generation-spanning continuity of their business, they are more likely to establish managerial objectives with stronger linkages to the long-term health of the organization than to short-term performance. Such long-term goals can be expected to stimulate middle managers to perceive the benefits of discontinuous technologies (Bower \& Gilbert, 2006), which typically pan out only in the long run (Anderson \& Tushman, 1990), and to support rather than to oppose their adoption. This effect is reinforced since members of a highly familyinfluenced business-owing to their sense of responsibility for the community and the social codices imposed by such a community-are more prone to accept decisions that are made to protect the long-term interests of the organization (Gómez-Mejía et al., 2001; Miller \& Le BretonMiller, 2005).

Moreover, the high levels of command associated with family influence soften political resistance. The power of key decision makers in family-influenced firms is typically nonnegotiable, primarily because that power relies on familial ties with the owners or relational aspects in the decision makers' contracts (Gómez-Mejía et al., 2001). Consequently, "turf battles" that slow the decision-making and interpretation processes (Hill \& Rothaermel, 2003; Pfeffer, 1992) are, ceteris paribus, less likely in strongly familyinfluenced environments. Prior research has suggested that command also has a sociocognitive impact (Kaplan, 2008) in the sense that the frames adopted and communicated by family executives are particularly likely to be adopted rapidly by their subordinates (Berrone, Cruz, Gómez-Mejía, \& Larraza-Kintana, 2010; Eddleston, 2008). For instance, Berrone et al. note that "even in publicly traded firms with greater ownership dispersion, the views of family members as a group are likely to demand a great deal of attention compared with those of nonfamily stakeholders" (2010: 88; see also Chrisman, Chua, \& Steier, 2003).

Proposition 3: Ceteris paribus, the stronger the fomily influence in a firm, the lower the level of political resistance of organizational members in that firm.

\section{Family Influence and Emotional Ties to Existing Assets}

A fourth, behavioristic approach to understanding variance in incumbents' adoption of discontinuous technologies assumes that decision makers feel emotionally tied to existing tangible and intangible resources within their firms and within the broader ecosystem surrounding their organizations (Burgelman \& Grove, 1996; Sydow et al., 2009). The stronger these emotional ties, the more "painful" (Tushman et al., 1986: 29) it becomes for managers to fully embrace discontinuous technologies, since such moves typically require managers to substantially reconfigure (human) resources, divest assets that previously constituted the firm's core, or reorchestrate (cross-)organizational architectures-for instance, by bypassing established complementors (Adner, 2012; Christensen, 1997; Teece, 2006).

We argue that family influence reinforces emotional ties to existing assets and architectures and that it magnifies the tendency of incumbent firms to avoid discontinuous organizational reconfigurations. Top managers in family-influenced businesses maintain intense, 
personal relationships within their organizations and with other actors in the environment (Miller \& Le Breton-Miller, 2005). Given this involvement in community and connections, family managers have more status to lose because they enjoy more "personal prestige in the community [and] social support among friends and acquaintances" (Berrone et al., 2010: 86) than managers in other companies. As a result, managers in highly fomily-influenced companies are less willing than managers in less familyinfluenced businesses to jeopardize social relations within the organization and with the external environment-for instance, by laying off staff or engaging in other actions that could significantly harm social ties (Berrone, Cruz, \& Gómez-Mejía, 2012; Sirmon \& Hitt, 2003). Therefore, in the context of discontinuous change, managers in family-influenced companies will attempt to transfer employees and managers from the old to the new business to minimize unrest, even though tenured employees may lack the skills, knowledge, and drive necessary to succeed in the new technological domain. These managers are also likely to continue collaborating with actors in the established "innovation ecosystem" (Adner \& Kapoor, 2010).

Proposition 4: Ceteris paribus, the stronger the family influence in a firm, the higher the level of decision makers' emotional ties to existing assets in that firm.

\section{Family Influence and Rigid Mental Models}

A fifth stream of research on organizational adaptation builds on theories of human and organizational cognition (Kaplan, 2011; Kaplan \& Tripsas, 2008; March \& Simon, 1958) and attributes heterogeneity in incumbents' adoption behaviors to variations in the rigidity of organizational members' mental models or "frames" (Kaplan, 2008). Mental models are relatively sticky cognitive schemata that can cause decision makers to focus their screening efforts on "local" developments (Nelson \& Winter, 1982)—a pattern that is often associated with firms' late recognition of discontinuous changes outside their narrow radar screens (Barr, Stimpert, \& Huff, 1992). Mental model rigidity is also pivotal in the context of the adoption of new organizational routines. Although actors have a certain amount of agency to adapt routines by "performing" them (Feldman \& Pentland, 2003), the speed and degree to which a newly performed routine deviates from a previous routine depend on the scope and the flexibility of the respective actor's mental model. As Feldman and Pentland note, "Each participant's understanding of a routine depends on his or her role and point of view" (2003: 101). Therefore, the less rigid the mental models of actors in an organization, the more flexibly it will adapt to drastic changes in the environment (Borr et al., 1992).

Mental models in established organizations are likely to become more rigid as family influence increases. Most important, as a result of the family system's focus on continuity, top management tenures lengthen with growing family influence (Berrone et al., 2010; Cruz, GómezMejía, \& Becerra, 2010; Gómez-Mejía et al., 2001; Schulze, Lubatkin, Dino, \& Buchholtz, 2001). Long tenures freeze the mental models used by top management, thereby inducing a kind of "tunnel vision" and reinforcing commitment to the status quo (Finkelstein \& Hambrick, 1990; GómezMejía et al., 2001: 86). Furthermore, top management teams become more homogeneous as family influence increases (Sirmon \& Hitt, 2003), and such homogeneity is also associated with fixed mental models and local search (Cho \& Hambrick, 2006). Notably, in highly familyinfluenced businesses, decision makers' rigid mental models can be expected to be particularly strong barriers to adoption given the high concentration of authority in such firms.

In addition, because of their strong sense of community, family-influenced companies are less likely to replace existing lower-level employees with new, differently trained staff (Miller \& Le Breton-Miller, 2006). This tendency entails longer employee tenures than in non- or less family-influenced companies (Haugh \& McKee, 2003), which, for reasons similar to those for longer management tenures, exacerbates cognitive inflexibility and the commitment to pathdependent strategic initiatives. Furthermore, low employee turnover reduces the diversity of frames and knowledge and, thus, stiffens mental models (Cho \& Hambrick, 2006).

A final key reason why family influence is positively associated with mental model rigidity is rooted in the fact that family influence entices decision makers to avoid incorporating external influence in organizational decision making 
and action (Gómez-Mejía et al., 2007). When companies involve external actors-particularly those from outside the traditional industry domain (Vasudeva \& Anand, 2011) —in their sensemaking and decision-making processes, the rigidity of mental models decreases (Gilbert, 2005), since those externals are typically less biased by traditional mental schemata (McDonald, Khanna, \& Westphal, 2008). However, "family[-influenced] firms are less likely to incorporate outsiders' perspectives and opinions in their decision making" (Gómez-Mejía, Makri, \& Larraza-Kintana, 2010: 224), because such companies hesitate to let go of command (Miller \& Le Breton-Miller, 2005) and to dilute family influence by involving external parties in focal strategic decisions. Moreover, organizational members of formily-influenced firms often form particularistic groups surrounded by "thick social walls" (Carney, 2005: 250) that separate them from outsiders and lower members' motivations to involve externals (Carney, 2005). In addition, the stronger the family influence in firms, the more they tend to establish stable connections with a few selected partners, rather than numerous connections with a larger number of partners (Miller \& Le Breton-Miller, 2005). This exclusivity of social ties is likely to shrink the number and diversity of external individuals who might provide access to complementary assets, including outside perspectives and "out-ofthe-box" business approaches, in the various phases of technology adoption.

Proposition 5: Ceteris paribus, the stronger the family influence in a firm, the higher the level of mental model rigidity among organizational members in that firm.

\section{TOWARD A MODEL OF FAMILY INFLUENCE AND ORGANIZATIONAL ADOPTION OF DISCONTINUOUS TECHNOLOGIES}

In the previous section we analyzed how family influence affects five particularly important barriers to the adoption of discontinuous technologies by incumbents. The most significant outcome of this theorizing is that fomily influence fundamentally shifts the challenges that organizations face when responding to technological discontinuities. This is because increasing family influence affects the levels of each of the inhibitors to discontinuous technology adoption, albeit not in a uniform way. The lower levels of formalization, dependence on external capital providers, and political resistance that coemerge with family influence should foster the adoption of discontinuous technologies. In contrast, stronger emotional ties to existing assets and the rigid mental models associated with family influence should aggravate the adoption challenges that firms face when discontinuous technologies arise.

In this section we reconcile the apparently equivocal implications of family influence by integrating our findings in a comprehensive yet granular model (see, in particular, the second half of Figure 1). This model breaks down the organizational adoption of discontinuous technologies into its key components, which we described above: speed (further divided into recognition, decision, and implementation speed), resource commitment (further divided into oggressiveness and stamina), and flexibility of adoption routines. The model outlines the relationships among the various barriers to adoption and, ultimately, provides an inclusive picture of the aggregated effects of family influence on the dimensions of discontinuous technology adoption.

\section{Family Influence and the Speed of Discontinuous Technology Adoption}

As noted earlier, the speed of incumbents' adoption of discontinuous technologies is a cumulated function of (1) the time incumbents take to recognize the innovation as a relevant strategic issue that requires a response (Kaplan et al., 2003), (2) the time incumbents take to decide to adopt the discontinuous technology (Christensen, 1997), and (3) the time incumbents take to implement the adoption decision by launching a first product based on the new technology (Lieberman \& Montgomery, 1988). Because the respective duration of each of these three adoption phases (Thomas et al., 1993) is not equally affected by each adoption barrier, we discuss the impact of family influence on each of the phases separately.

Family influence and speed of recognition. The attention-based view of the firm (Ocasio, 1997) points out that organizations must first recognize an issue as relevant to their own business before they decide whether, when, or how 
to respond to that issue (Kaplan et al., 2003). In our analysis of the individual barriers of adoption, we have highlighted that the recognition of discontinuous technologies is delayed by two specific factors (Ahuja et al., 2008; Hill \& Rothaermel, 2003): (1) high levels of formalization and (2) rigid mental models. Both barriers have been described in the literature as narrowing on organization's "search radius" or "radar screen" (Hannan \& Freeman, 1984; Nelson \& Winter, 1982), thereby lowering the odds that a discontinuity will be detected at an early stage (Kaplan et al., 2003). We have also shown that family influence lowers the levels of formalization (Proposition 1) while simultaneously increasing the rigidity of organizational members' mental models (Proposition 5). This raises one focal question: how is family influence generally associated with speed of recognition?

To answer this question, we draw on Feldman and Pentland's (2003) distinction between ostensive and performative elements of routines, which helps us to understand the interactions between the formalization of organizational structures and the cognitive structures of individual actors. According to Feldman and Pentland (2003), a reduction in the level of structural formalization implies that individual actors have more agency to performatively alter routines of organizational search and to monitor the environment for changes outside the established radar screen, and thus increases the probability that discontinuous changes are recognized. However, Feldman and Pentland's model also implies that the more individual organizational actors have agency to adapt routines by performing them, the more the qualities of these individuals' mental models-especially the rigidities of their cognitive structures-will influence the search for and the eventual recognition of discontinuous change.

We expand on Feldman and Pentland's thoughts to argue that, contrary to what one would expect based on standard theory (Hannan \& Freeman, 1984), the lower levels of formalization associated with increased family influence do not lead to faster recognition of discontinuous technologies. Instead, if (1) the mental models of actors-particularly the rigidity of those mental models-become more determinant of organizational search routines as a consequence of family-induced relaxation of structure and (2) the mental models of the individual ac- tors that perform search routines simultaneously become narrower and more rigid with increasing family influence, then organizational actors in highly family-influenced firms are less likely to search outside their traditional, narrow cognitive templates (their mental "home turf" [Livengood \& Reger, 2010]) or to radically and flexibly adapt search routines. In fact, these actors will be more likely to reproduce and freeze the existing cognitive template. In other words, family influence, mediated by the interplay of coemerging higher flexibility of search routines and higher mental model rigidity of organizational members, retards organizational recognition of discontinuous change. Moreover, even if managers in family businesses become aware of a breakthrough, rigid mental models induce them to downplay its impact-for instance, by interpreting the information as confirmation of the existing business logic's superiority.

For example, imagine two incumbent publishing houses-one highly fomily influenced and the other one less fomily influenced. According to Proposition 1, in the first company (say, for instance, the highly formily-influenced market leader of printed dictionaries in Germany, Langenscheidt, in the early 2000s) there will be relatively few formal rules for identifying and interpreting upcoming innovations, such as online publishing and user-generated content. However, as predicted by Proposition 5, employees in this firm generally will know comparatively little about online business models or the Internet. Furthermore, they will show little interest in this new technological domain because most of their work experience and business contacts will have been limited to the realm of physical publishing. To further complicate matters, these employees will use their agency to focus search processes on innovations around printed publishing (e.g., new layouts, topic areas, or authors). In contrast, employees of a less familyinfluenced publisher (such as the publicly listed Dutch company Wolters Kluwer) will more readily grasp the business implications of innovations such as tablet computing, e-books, and social networks, despite formal search rules and interpretation standards imposed by institutional forces and market pressures (see Proposition 1), because these individuals will possess complementary knowledge and change mindsets more flexibly (Proposition 5). 
Proposition 6a: Ceteris paribus, the stronger the family influence in a firm, the later that firm will recognize a discontinuous technology as a relevant strategic issue.

Family influence and speed of adoption decisions. Standard discontinuous change research (e.g., Christensen \& Bower, 1996) attributes the slowness of adoption decisions to the innovator's dilemma (Christensen, 1997). Initially, discontinuous innovations are inherently difficult to assess in terms of profitability and growth; thus, incumbent firms-even if they are fully aware of such an innovation-are motivated to decide to adopt the innovation only when the business case has become sufficiently predictable to legitimize an investment in the eyes of external investors, particularly capital markets (Christensen \& Raynor, 2003). The classical account also holds that formalized decision procedures and political resistance further prolong a potential adoption decision (Hannan \& Freeman, 1984).

The addition of the family factor to this textbook picture leads to a different story, although with similar inertial outcomes. Family influence lowers dependence on external capital providers and reduces levels of formalization and political resistance. It thus creates significant structural leeway for actors to make autonomous adoption decisions. In brief, the innovator's dilemma, as traditionally envisaged, is less important for "family innovators."

However, because family influence entails increased emotional ties to existing assets, decision makers in family-influenced firms face a different challenge, which we call the "family innovator's dilemma." Executives in highly family-influenced firms can only choose between two suboptimal choices after they have recognized the need to respond to a discontinuous technology. They can choose to not adopt the innovation and, thus, endanger the long-term health of the company (and thereby the transgenerational wealth of the family system). Alternatively, as we discussed when developing Proposition 4, they can choose to disrupt social relations as well as cognitive and architectural systems in the short term by adopting the innovation, thereby also imperiling crucial noneconomic values that are essential to family businesses. Only after the dominant coalition has overcome this emotional struggle can these managers use the decision autonomy and "cognitive authority" that stem from decreased formalization, less resource dependence, and lower political resistance to promptly decide to implement the discontinuity.

The family innovator's dilemma involves managerial considerations of socioemotional wealth in family-influenced firms (Berrone et al., 2010; Gómez-Mejía et al., 2007) and, thus, touches upon the very foundations of the fomily system. Executives will struggle to resolve this quandary, which, in turn, will protract their decisions related to the adoption of discontinuous technologies. The case of Siku, a 90-year-old familyowned German manufacturer of toy car models, exemplifies the effects of the family innovator's dilemma. Siku, which daily sells 45,000 car models, did not decide to sell new models via the Internet until 2012, despite customer requests for such a service. On its website Siku justified its long-time abstinence from e-commerce by stating that direct online sales would harm longterm sales partners and would therefore damage the fair-play attitude of this family firm.

Based on the equiconsequential effects of the traditional innovator's dilemma and the family innovator's dilemma, it is impossible to hypothesize that fomily influence causes variance in adoption decision speed. However, as we discuss below, decrypting these two dilemmas is crucial since it helps us to carve out fundamental differences in the adoption mechanisms resulting from variance in formily influence. Moreover, the identification of the family innovator's dilemma is central to our subsequent theorizing, for it allows us to derive nomological propositions related to other adoption dimensions.

Family influence and speed of adoption implementation. The last phase that determines the speed of organizations' adoption of discontinuous technologies encompasses the time that elapses between the decision to adopt the new technology and the launch of the first product that builds on this innovation. In the classical view the implementation of adoption decisions is often stalled by bureaucracy (rooted in high levels of formalization) and political resistance among organizational members (Hill \& Rothaermel, 2003). Our theorizing (Propositions 1 and 3) allows us to conclude that, ceteris paribus, family influence enables firms to implement discontinuous technologies faster than other compa- 
nies once the adoption decision has been made. Lower levels of bureaucracy and fewer internal and external "checks and balances" (Carney, 2005) allow family managers to act freely and promptly. In contrast, managers in more formalized environments, particularly capital marketoriented firms, must act within a relatively tight corset when making decisions (Hoskisson, Hitt, Johnson, \& Grossman, 2002). Furthermore, in highly fomily-influenced firms, the momentum of technology implementation is less thwarted by political resistance than in other firms (Sirmon \& Hitt, 2003), as we highlighted in our development of Proposition 3.

Proposition 6b: Ceteris paribus, the stronger the family influence in a firm, the faster that firm will implement a discontinuous technology after having made the decision to adopt this innovation.

In conjunction, the retarding effect of fomily influence on recognition (Proposition 6a) is offset by its accelerating effect on the speed of implementation (Proposition 6b). Given this stalemate and the fact that it is impossible to predict how family influence impacts the speed of adoption decisions, we refrain from proposing a categorically positive or negative association between family influence and discontinuous technology adoption speed.

\section{Family Influence and Resource Commitment to Discontinuous Technology Adoption}

Adoption speed does not necessarily covary with the amount of resources organizations commit to technology adoption. For instance, on the one hand, although physical book retailers in many countries adopted e-commerce relatively early, they invested relatively few resources, especially compared to Amazon. On the other hand, many traditional pharmaceutical companies entered biotechnology relatively late, but they then invested very aggressively (Kaplan et al., 2003). Therefore, we look at these two dimensions separately. Furthermore, as noted above, we conceptually separate resource commitment into (1) aggressiveness of resource commitment-the amount of resources allocated annually to the development and commercialization of a discontinuous technology and (2) adoption stamina-the time span over which a company sustains a certain level of resource commitment to the exploration of such a breakthrough innovation despite initial setbacks.

Family influence and aggressiveness of resource commitment. The classic portrayal of the innovator's dilemma (Christensen, 1997) suggests that external providers of capital (both debt and equity) are likely to require higher premiums for providing funds to invest in discontinuous, as opposed to continuous, technologies (Benner, 2007, 2010). The resulting higher costs of capital for discontinuous technologies incentivize the dominant coalition in established organizations to limit the resources allocated to the adoption of such innovations. High levels of formalization, together with compromises to pacify political resistance, further reduce the aggressiveness of resource commitment to discontinuous technologies.

Family influence frees businesses from the classical innovator's dilemma because the family system aims to remain independent of external providers of capital. Family influence also engenders lower levels of formalization and political resistance. Accordingly, an increase in formily influence might be expected to reinforce adoption aggressiveness. However, we argue the contrary. Family owners actively attempt to maintain command over their company by avoiding external funding (Gómez-Mejía et al., 2001; Mishra \& McConaughy, 1999; Schulze et al., 2003). The flip side of this self-imposed investment restriction is that the more a company is family influenced, the more the maximum amount of money that it can commit to the discontinuous technology becomes a function of that firm's internal free cash flow, which is a priori limited. Thus, even if higher fomily influence liberates firms from the constraints imposed by external capital providers and reduces formalization and political resistance, resource allocation in these firms will, ceteris paribus, be capped by a certain commitment ceiling. In contrast, less family-influenced companies will not be constrained by endemic barriers to tapping external capital.

Their self-imposed commitment ceiling renders highly family-influenced firms particularly reluctant to aggressively adopt discontinuous technologies, and this effect is subtly exacerbated by interacting with the family innovator's dilemma. Every dollar spent on the discontinuous business is unavailable for the continuous 
business and, thus, potentially undermines the community. Given that the current well-being of the community is a fundamental emotional decision parameter of the family system and that individuals value current wealth more than future wealth (Gómez-Mejía et al., 2007; Loewenstein \& Thaler, 1989), decision makers in highly fomily-influenced firms will refrain from aggressively investing in discontinuous technologies. This hesitance is likely to grow as funds available for investments shrink, because each dollar invested in the discontinuity is then viewed as even more harmful for the current business. Finally, the mental model rigidity that stems from family influence additionally entices actors to favor established solutions over new paradigms (see Proposition 5).

Proposition 7a: Ceteris paribus, the stronger the family influence in a firm, the lower that firm's aggressiveness of discontinuous technology adoption.

Family influence and stamina of resource commitment. As described in the discontinuous change literature, incumbents typically struggle to sustain resource commitments to discontinuous change because of their resource dependence, high levels of formalization, and political resistance (Hill \& Rothaermel, 2003). Discontinuous innovations tend to evolve over a sustained period of time (Christensen, 1997) and inherently involve setbacks (Tushman \& Anderson, 1986). Furthermore, growth rates and profits generated by breakthrough innovations typically tend to remain low for an extended period before reaching a tipping point where they start to grow rapidly (Utterback \& Abernathy, 1975). External capital providers, however, are impatient for growth and profits (Benner, 2010; Bushee, 2001; Christensen, 1997). In addition, formalized resource allocation processes in established organizations reinforce organizational preferences for efficiency and reproduction and, therefore, provide further impetus for the abandonment of high-variance innovations (Farjoun, 2010; Hannan \& Freeman, 1984). Finally, setbacks create tailwinds for opponents of the discontinuous technology, raising the odds of early abandonment (Kotter, 2007).

Family influence frees companies from such constraints as it coemerges with independence from short-term-oriented providers of capital and, thus, releases businesses from the invest- ment ties that restrain the long-term momentum of resource commitment to discontinuous change. Furthermore, fomily influence leads to a more long-term-oriented, continuity-focused approach to strategy making. Therefore, as highlighted in fomily business research, fomily influence creates "patient capital"-that is, "financial capital [that] is invested without threat of liquidation for long periods" (Sirmon \& Hitt, 2003: 343). Additionally, given their commitment to the community, organizational members in highly family-influenced firms will be less involved in political "upheaval" (Tushman et al., 1986), which can otherwise stall the impetus (Bower, 1970) of technology adoption. In this vein Rumelt (2011: 67) noted the "iron nerves" of private, family-influenced companies when elaborating on Roll International Corporation's successful management of discontinuous innovations.

Proposition 7b: Ceteris paribus, the stronger the family influence in a firm, the higher the stamina of that firm's discontinuous technology adoption.

\section{Family Influence and the Flexibility of Discontinuous Technology Adoption}

The timely and continuous commitment of a certain level of resources to the exploration of a discontinuous technology is necessary, but not sufficient, to successfully adopt such a breakthrough. The flexible adoption of nonparadigmatic internal routines is at least equally important (Gilbert, 2005; Tripsas \& Gavetti, 2000). In line with the extant literature (Kaplon \& Tripsas, 2008), we argue that the flexibility of routines is mainly determined by the extent to which two specific barriers to adoption-formalization and rigid mental models-are prevalent in the focal organization. Similar to our discussion leading to Proposition $6 a$, we argue that, in conjunction, the inertia-enhancing effects of family influence stemming from higher mental model rigidity can be expected to more than offset the inertiarelaxing effects of fomily influence stemming from decreasing levels of formalization.

Specifically, we posit that family influence engenders flexibility, albeit only within norrow cognitive and behavioral boundaries. This argument builds again on Feldman and Pentland's (2003) conceptualization of organizational rou- 
tines, which has two implications: (1) the degree to which a routine deviates from previous routines is ultimately a function of the experiences, dispositions, and mental structures of the performing actors, and (2) the slope of this function increases depending on the degree of these actors' agency. It follows that the increased rigidity of organizational members' mental models is a crucial inhibitor of routine flexibility in highly fomily-influenced firms-individuals with norrow and sticky mental models and simultaneously high degrees of agency can be expected to develop new routines that are inside their constricted cognitive boundaries. In contrast, despite stronger structural formalization, adoption routines in less family-influenced firms are likely to be less rigid because they are performed by actors with flexible and broad mental models.

The jazz metaphor, which has been evoked repeatedly by organization scholars (Weick, 1998), provides a rich conceptual source to illustrate our reasoning. Imagine two groups of highly versatile jazz musicians: the first group is specialized in a narrow set of styles, such as Dixie and swing, and treasures close relationships embedded exclusively within those musical microcosms; the second group has heterogeneous experiences in a broad array of musical styles and multifold and fluctuating contacts within and outside the music world. Now imagine that (for whatever reason) the first group plays in a combo formation, which is characterized by few standards in terms of melody, chords, and improvisatory "licks" (representing the highly formily-influenced firm). The second group joins a Glenn Miller style big band, where musicians play from a score, improvisation is limited to short solos, and the stylistic canon is relatively fixed (the less family-influenced firm). How likely is it that the two groups will adopt new paradigms in response to drastically changing audience preferences and upcoming breakthroughs in synthesizing, composing, and performing? We argue that actors in the first group will stick to Dixie and swing. They will adapt routines by improvising, but because of their specific knowledge and skills and their appreciation of stable contacts, they will be less likely to grasp and explore the value of new domains and to change the setup of the group. Thus, their adaptations will remain within, and will reinvigorate, the idiosyncratic musical id- iom of established performative terrains. In contrast, musicians in the second group can be expected to slowly mold styles and, despite their limited leeway, to bring in differently trained colleagues, to try out new instruments, and to eventually morph Glenn Miller swing into a new genre-still formalized, perhaps, but pathbreakingly different.

In addition to these effects, family influence reduces adoption flexibility as a result of increased emotional attachment to existing assets. The embracing of path-diverging routines typically requires drastic shifts in a firm's resources (Gilbert, 2005)-for instance, production facilities-and thus tends to contradict the family system's most fundamental values (see Proposition 4).

Proposition 8: Ceteris paribus, the stronger the family influence in a firm, the lower that firm's flexibility in discontinuous technology adoption routines.

\section{DISCUSSION}

Our goal has been to advance our knowledge of when and how established companies adopt discontinuous technologies by integrating a new factor into the equation: the impact of the family system on the business system. Specifically, we provide a detailed account of how increases in fomily influence affect the fundamental barriers to discontinuous technology adoption and, ultimately, the speed, aggressiveness, stamina, and flexibility with which incumbents embrace such breakthroughs to create and capture value. The leitmotif of our theorizing is the notion that the role of family influence is of substantial importance for our understanding of discontinuous technology adoption because companies whose businesses are closely interlinked with a family system operate under fundamentally different constraints than those-typically public-companies that stand in the spotlight of standard theory on discontinuous technological change. The exploration of these fomily-induced interpretive, normative, and structural differences, along with the resulting comprehensive picture of their interrelations, leads us to challenge critical assumptions underlying textbook explanations of incumbents' adoption of discontinuous innovations 
(Hill \& Rothaermel, 2003), including the paradoxes and dilemmas involved (Christensen, 1997). In this regard, three aspects are particularly noteworthy.

First, we challenge the notion that the classical innovator's dilemma, as formalized by Christensen (1997), is generalizable to all firms. Instead, we introduce the concept of the family innovator's dilemma to capture the idiosyncratic struggle that family influence adds to the challenge of organizational adoption of technological discontinuities. Family influence frees companies from the traditionally described constraints that are imposed on firms by external providers of capital (Benner, 2007; Christensen, 1997). However, formily influence entails increased emotional ties to existing assets and, consequently, forces managers to confront a different decision dilemma: they either undermine fomily influence in the long term by abstaining from a discontinuous technology, or they undermine family influence in the short term by breaking with established interpretive, structural, and relational ties. Moreover, because the formily system self-imposes on overall investment ceiling in the quest to transfer wealth to future generations, every investment in the discontinuous technology endemically diminishes the funds available for established technologies. As such, the growing independence from external capital providers that emerges with increasing fomily influence, the family innovator's dilemma, and the general tendency of decision makers to prefer current wealth to future wealth together protract adoption decisions in familyinfluenced firms and reduce adoption aggressiveness below the level of other companies.

Second, contrary to structural inertia theory, we argue that reduced formalization does not $a$ priori relax inertial forces and does not necessarily trigger faster, more flexible adoption of discontinuous technologies (Hannan \& Freeman, 1984). Instead, our analysis suggests that the inertia-breaking effect that stems from fewer formal structures is bounded by the rigidity of actors' mental models: the more actors are cognitively constrained by mental model rigidity, the less likely these individuals will be to use their increased agency to drastically alter routines when performing them. As such, given that family influence simultaneously relaxes organizational structures but freezes individual cognitive structures, formily influence results in less open search and less flexible routine adaptation. In synthesis, despite its lower degrees of formalization, family influence manifests itself in protracted recognition of discontinuous technologies and reduced adoption flexibility.

Finally, considering the family factor allows us to highlight the distinctiveness and importance of adoption stamina as a manifestation of resource commitment to technological discontinuities. In the organization literature the notion of strategic patience, or stamina, has primarily been discussed with a negative connotation under such labels as organizational persistence (Finkelstein \& Hambrick, 1990) and escalation of commitment (Staw, 1981). Implicitly, the discontinuous change literature paints a more positive picture by noting that, in this context, stamina can pan out, since incumbent firms are prone to abandon discontinuous technologies too early in response to pressure from investors (Benner, 2007; Christensen, 1997) and organizational members (Hannan \& Freeman, 1984). In a somewhat similar vein, the family business literature has presented the concept of "patient capital" (Sirmon \& Hitt, 2003: 340) as a competitive advantage of family-influenced firms. However, our analysis is the first to explicitly reframe stamina as a (potentially) productive ingredient in adoption performance and the first to denote family influence as a key ingredient in adoption stamina.

Given the discipline-bridging setup of our theorizing, our model also has critical implications for family business research. Scholars in this field have long sought to identify whether family influence is a benefit or a burden for businesses (O'Boyle et al., 2012), but with equivocal results. Building on agency theory as a common theoretical perspective, some authors have argued that fomily influence is beneficial, reducing the necessity to monitor family-related and family-loyal agents (e.g., Foma \& Jensen, 1983). Other scholars, in contrast, have pointed to an increase in agency costs in family-influenced firms caused by parental altruism, nepotism, and entrenchment (Schulze et al., 2003). In a recent metastudy O'Boyle et al. noted that empirical evidence is similarly inconclusive and therefore called for "more fine-grained theory building" and the "development and testing of potential moderators" (2012: 13). We respond to this call by shifting our attention upstream in the causal chain toward a specific precedent of 
long-term firm performance: the adoption of technological discontinuities. We also differentiate among various subdomains of the key variables and several underlying mechanisms, which enables us to dissect the complexities involved when studying the impact of family influence on strategic behavior, such as the interplay between lower levels of formalization and more rigid mental models.

In so doing, we provide rich clues to better understand the performance implications of family influence in the context of discontinuous change. A major insight is that family influence is dysfunctional in situations that require fast recognition of discontinuous technologies, as well as aggressive investment in those technologies and flexible implementation routines. In such situations the cognitive and emotional boundaries to adoption that are inherent in the family system are particularly important, for they prevent businesses from appropriately adapting to the emerging change. For instance, high levels of family influence could be one reason why German book publishers, such as DuMont, responded relatively late, timidly, and arguably rigidly to the emergence of e-publishing.

Perhaps even more interesting is our insight that family influence provides significant advantages once decision makers in familyinfluenced businesses understand the dilemmas that arise from family influence and overcome the cognitive-emotional hurdles to adoption. Family influence enables companies to implement adoption decisions faster and to sustain their investments over longer periods of time, despite setbacks. However, our research also implies that if highly family-influenced companies make their knowledge bases heterogeneous and stretch the mental models of their members, they will transform the agency that organizational members gain from increasing family influence- $a$ latitude that managers in other companies inherently do not enjoy (Benner, 2007)-into more flexible, successful adoption of discontinuous technologies. This pattern might explain the success of the familyowned German Otto Group, today the second largest online retailer worldwide. Otto Group executives have stated that they deliberately developed complementary knowledge in e-commerce and used their patient capital to cautiously but continuously invest in Internet retail- ing and to overcome numerous failures in early attempts to move online.

In addition, our research has important implications for practice. In particular, we highlight that the more a business is family influenced, the more its managers should engage in measures to relax the cognitive structures of organizational members. The approaches that are typically applied, such as diverse knowledge acquisition or debiasing (Milkman, Chugh, \& Bazerman, 2009), seem appropriate in this regard. Furthermore, we suggest that managers in family-influenced firms systematically analyze how their sense of community might lead them to overly avoid paradigm-breaking influences and initiatives. More important but also more challenging for highly fomily-influenced businesses is the introduction of tactics to break down the "thick social walls" (Carney, 2005) that fence in the business system from external knowledge and advice. In addition, constructive conflict, particularly regarding tasks and processes (Kellermanns \& Eddleston, 2004), could be generated through participative generational involvement in fomily firms (Chirico, Sirmon, Sciascia, \& Mazzola, 2011; Kellermanns, Eddleston, Barnett, \& Pearson, 2008).

Other approaches that may increase the likelihood of adoption among more fomily-influenced firms relate to financing and organizational architectures. To grab the family innovator's dilemma by the horns, external capital providers could emphasize the creation of financing packages that would allow family businesses to access abundant capital resources without ceding control. To lower rigidities in implementation routines, formily-influenced businesses could implement discontinuous technologies in loosely decoupled structures, which would enable them to unfreeze mental models and to foster experimentation and improvisation (O'Reilly \& Tushman, 2008). However, because decoupled architectures conflict, by definition, with the family system's preference for centralized command at the top of the organizational pyramid (Berrone et al., 2012), businesses with high levels of family influence should cultivate "contextual" forms of ambidexterity (Raisch \& Birkinshaw, 2008).

Finally, the notion of patient capital that we reinvigorate underlines that the characteristics of prototypal family businesses are also important for non- or less family-influenced firms. Specifically, we suggest that all companies in- 
stall "family-like" governance systems that liberate them from the constraints that penalize technological mistakes and setbacks and that provide them with more autonomy for dealing with such challenges.

\section{LIMITATIONS AND FURTHER RESEARCH}

As with any theory, our model builds on $\alpha$ number of assumptions that serve as important boundary conditions while also providing avenues for future research. Most important, scholars could scrutinize the generalizability of our propositions by questioning whether they hold under varying circumstances. One important factor in this context is the varying power dynamics in family businesses. Our model is grounded on the assumption that family influence has similar effects on the organizational adoption of discontinuous technologies regardless of the specific, case-idiosyncratic weight with which the overlap of the family and the business systems is reflected in each of the Four Cs. In this regard, one might expect specific sources of family influence to enhance some indicators of family influence more than others. For instance, power from formal ownership could reinforce the continuity dimension more than the other three dimensions, whereas family influence exerted through management could have a disproportional effect on the command dimension. For the sake of parsimony, we also refrain from taking into account the possibility that different forms of owner influence, such as voting and cash flow rights (deAngelo \& deAngelo, 1985), might affect each of the Four Cs differently. An elaboration of our model that integrates these issues could provide a promising avenue for future research.

Furthermore, we suggest refining our theory by studying the interactive roles of conflict and family influence (Gersick, 1997) in the context of discontinuous change. Prior research suggests that moderate (in comparison with low or high) levels of task and process conflicts stimulate open discussions and out-of-the-box thinking and that they are therefore beneficial to firm performance for businesses in general and for family businesses in particular (Kellermanns \& Eddleston, 2004, 2007). In this light, task and process conflicts could be expected to serve as a way to accelerate the recognition of discontinu- ous innovations (task conflicts) and to overcome routine rigidity (process conflicts).

Equally important, although different in their implications, are relationship conflicts in firms. In contrast to other types of conflicts, relationship conflicts have been described as inherently dysfunctional, particularly in highly fomilyinfluenced firms (Kellermanns \& Eddleston, 2004) where relational contracts are based more on trust and emotion (Gómez-Mejía et al., 2001) and where members of owning families are "locked" to their business (Kellermanns \& Eddleston, 2004). One might expect relationship conflicts in organizations to affect the link between family influence and discontinuous technology adoption because such conflicts are likely to diminish, or even reverse, the sense of community and continuity that family influence typically entails. Thus, if decision making in family-influenced organizations is overshadowed by relationship conflicts, perhaps as a consequence of high ownership dispersion (Kellermanns \& Eddleston, 2007), all effects that we conceptualize as being rooted in the family system's sense of community (e.g., the formily innovator's dilemma) are likely to be affected.

Moreover, the level of conflict in a firm is likely to distort the relationship between family influence and political resistance among organizational members. We argue that family influence reduces political resistance because of the nondebatable power enjoyed by family leaders, as well as the loyalty and commitment of organizational members to the organization. However, one could argue that if a family-influenced company is affected by severe relationship conflicts, then organizational members will become dissatisfied and frustrated (Eddleston \& Kellermanns, 2007). In turn, relationship conflicts can increase the level of political resistance and, thus, affect our theory, particularly our propositions on the effect of formily influence on the speed of adoption (Proposition 6b) and on resource commitment to discontinuous technologies (Propositions 7 $\alpha$ and b). Nevertheless, given the imminent complexities involved in intraorganizational conflict (Kellermanns \& Eddleston, 2004), as well as the ambiguous empirical results (Kellermanns \& Eddleston, 2007), we leave it to subsequent research to fully explore the implications of varying levels of conflicts in the context of the theme of our study. 
Future studies could also increase the generalizability of our theory by studying the effects of the personalities and dispositions of individual key decision makers in an organization (Chua et al., 1999). As highlighted in upper echelons theory (Hambrick \& Mason, 1984), the more influence key decision makers wield in an organization, the more their experiences, values, and personalities shape organizational outcomes (Finkelstein, Hambrick, \& Cannella, 2009). In addition, personality-outcome associations are amplified in ambiguous and uncertain situations (Mischel, 1977). Therefore, the characteristics of the members of the dominant coalition are likely to affect organizational responses to technological discontinuities, particularly in formily-influenced firms with high levels of command (Minichilli, Corbetta, \& MacMillan, 2010).

Furthermore, we encourage scholars interested in the impact of family influence on firm innovation to differentiate between discontinuous and continuous technologies. For instance, we suggest that such a distinction could be insightful when extending the recent study by Chrisman and Patel (2012), which shows that threat perception is linked to higher marginal increases in R\&D investments in family businesses than in other firms. Integrating Chrisman and Patel's (2012) theories with those presented here could enrich future research, since the positive interactive effect of family influence and threat perception on innovation investments could depend on the nature of the change studied. For instance, if family-influenced firms feel threatened by a discontinuity and react by investing in the respective continuous technology to defend their position, while also selfrestricting their access to capital, then the resources available for the discontinuity decrease as threat perception increases. Thus, threat perception in formily-influenced firms could result in lower investments in discontinuous technologies.

Finally, theorizing on the effect of family influence on complex forms of organizational ambidexterity and resulting adoption patterns seems particularly promising. Ultimately, such studies could help to develop customized variations of ambidexterity-for instance, based on the notions of contextual and temporal ambidexterity (Gibson \& Birkinshaw, 2004). Such organizing would not contradict the family system's need for command and control as much as the structurally decoupled architectures recom- mended in the standard literature to render the implementation of discontinuous technologies more flexible (Tushman \& O'Reilly, 1996).

Given the complexity of the underlying mechanisms as well as the temporal structure of our model, we suggest testing our theory using longitudinal, multimethod research approaches in different empirical backgrounds. Interpretive, case-based research (Eisenhardt, 1989; Yin, 2008) along with standard quantitative approaches could be used to test and extend our model with data from industries comprising a larger number of at least midsize players, encompassing a sufficient degree of variance in family influence, and undergoing (or having recently undergone) discontinuous technological change (e.g., newspapers and publishing).

Scholars can build on the firm ground of extant research when measuring and manipulating the key concepts in our model. We suggest that measures of formily influence be guided by Miller, Le Breton-Miller, and Scholnick's (2008) approach to gauging the Four Cs and that they be enriched by the advances in describing and capturing socioemotional wealth orientation in firms recently presented by Berrone et al. (2012). Approaches to operationalizing the dependent constructs exist in most cases. "Adoption speed" (in its overall definition) should be a time measure reflecting, for instance, the number of years from the time the first company makes an adoption investment to the time the focal firm makes an adoption investment (Eggers \& Kaplan, 2009). "Adoption aggressiveness" and "stamina" are self-explanatory. Only the "flexibility of adoption" is challenging to measure, since doing so likely requires access to confidential firm data. As recently reiterated by fomily business scholars (e.g., Berrone et al., 2012; Zachary, McKenny, Short, \& Payne, 2011), unobtrusive measures could be useful in this regard, particularly those relying on content analysis (Krippendorff, 2004) of textualized company material, such as company reports, websites, presentations, interviews, and transcribed conference calls.

\section{CONCLUSION}

Within the conversation on organizational adaptation, our research reiterates the importance of different forms of governance in general and fomily influence in particular in the context of discontinuous change. These crucial topics have 
only been brushed tangentially, if at all, in the extant literature (Ahuja et al., 2008; Hoskisson et al., 2002). As such, this study provides a new perspective to explain why established players adopt discontinuous technologies heterogeneously rather than homogeneously.

In conclusion, our theorizing shows that family influence is a powerful force affecting organizational adaptation to discontinuous change. Family systems influence firms at the relational, interpretive, and structural levels of organizations, and their presence means that decision makers face particularly emotional strugglesincluding the family innovator's dilemma-that differ from those highlighted in prior literature. Regardless of the methodology used to scrutinize this research, we hope our theorizing stimulates multifold conversations and empirical studies that could lead to a deeper understanding of established organizations' responses to discontinuous change and family influence.

\section{REFERENCES}

Abernathy, W. J., \& Clark, K. B. 1985. Innovation: Mapping the winds of creative destruction. Research Policy, 14: 3-22.

Adner, R. 2012. The wide lens: $A$ new strategy for innovation. London: Penguin.

Adner, R., \& Kapoor, R. 2010. Value creation in innovation ecosystems: How the structure of technological interdependence affects firm performance in new technology generations. Strategic Management Journal, 31: 306-333.

Ahuja, G., Lampert, C. M., \& Tandon, V. 2008. Moving beyond Schumpeter: Management research on the determinants of technological innovation. Academy of Management Annals, 2: 1-98.

Anderson, P., \& Tushman, M. L. 1990. Technological discontinuities and dominant designs: A cyclical model of technological change. Administrative Science Quarterly, 35: 604-633.

Anderson, R. C., \& Reeb, D. M. 2003. Founding-family ownership and firm performance: Evidence from the S\&P 500. Journal of Finance, 58: 1301-1328.

Arregle, J.-L., Hitt, M. A., Sirmon, D. G., \& Very, P. 2007. The development of organizational social capital: Attributes of family firms. Journal of Management Studies, 44: 7395.

Arrow, K. J. 1974. The limits of organization. New York: Norton.

Asstrachan, J. H., Klein, S. B., \& Smyrnios, K. X. 2002. The F-PEC scale of family influence: A proposal for solving the family business definition problem. Family Business Review, 15: 45-58.
Barr, P. S., Stimpert, J. L., \& Huff, A. S. 1992. Cognitive change, strategic action, and organizational renewal. Strategic Management Journal, 13(Special Issue): 15-36.

Benner, M. J. 2007. The incumbent discount: Stock market categories and response to radical technological change. Academy of Management Review, 32: 703-720.

Benner, M. J. 2010. Securities analysts and incumbent response to radical technological change: Evidence from digital photography and internet telephony. Organization Science, 21: 42-62.

Berrone, P., Cruz, C., \& Gómez-Mejía, L. R. 2012. Socioemotional wealth in family firms: Theoretical dimensions, assessment approaches, and agenda for future research. Family Business Review, 25: 258-279.

Berrone, P., Cruz, C., Gómez-Mejía, L. R., \& Larraza-Kintana, M. 2010. Socioemotional wealth and corporate responses to institutional pressures: Do family-controlled firms pollute less? Administrative Science Quarterly, 55: 82113.

Block, Z., \& MacMillan, I. C. 1985. Milestones for successful venture planning. Harvard Business Review, 63(5): $184-$ 190.

Bower, J. L. 1970. Managing the resource allocation process. Boston: Harvard University, Division of Research.

Bower, J. L., \& Gilbert, C. 2006. Manage resource allocation to craft strategy. Working Paper, Harvard Business School, New Haven, CT..

Burgelman, R. A., \& Grove, A. S. 1996. Strategy dissonance. California Management Review, 38(2): 8-28.

Bushee, B. J. 2001. Do institutional investors prefer near-term earnings over long-run value? Contemporary Accounting Research, 18: 207-246.

Carney, M. 2005. Corporate governance and competitive advantage in family-controlled firms. Entrepreneurship Theory and Practice, 29: 249-265.

Chesbrough, H. W. 2001. Assembling the elephant: A review of empirical studies on the impact of technical change upon incumbent firms. In R. A. Burgelman (Ed.), Research on technological innovation, management and policy (7th ed.): 1-36. Greenwich, CT: JAI Press.

Chirico, F., Sirmon, D. G., Sciascia, S., \& Mazzola, P. 2011. Resource orchestration in family firms: Investigating how entrepreneurial orientation, generational involvement, and participative strategy affect performance. Strategic Entrepreneurship Journal, 5: 307-326.

Cho, T. S., \& Hambrick, D. C. 2006. Attention as the mediator between top management team characteristics and strategic change: The case of airline deregulation. Organization Science, 17: 453-469.

Chrisman, J. J., Chua, J. H., \& Kellermanns, F. W. 2009. Priorities, resource stocks, and performance in family and nonfamily firms. Entrepreneurship Theory and Practice, 33: 739-760.

Chrisman, J. J., Chua, J. H., \& Steier, L. P. 2003. An introduction to theories of family business. Journal of Business Venturing, 18: 441-448. 
Chrisman, J. J., Kellermanns, F. W., Chan, K. C., \& Liano, K. 2010. Intellectual foundations of current research in formily business: An identification and review of 25 influential articles. Family Business Review, 23: 9-26.

Chrisman, J. J., \& Patel, P. 2012. Variations in R\&D investments of family and non-family firms: Behavioral agency and myopic loss aversion perspectives. Academy of Management Journal, 55: 976-997.

Christensen, C. M. 1997. The innovator's dilemma. Boston: Harvard Business School Press.

Christensen, C. M., \& Bower, J. L. 1996. Customer power, strategic investment, and the failure of leading firms. Strategic Management Journal, 17: 197-218.

Christensen, C. M., \& Raynor, M. E. 2003. The innovator's solution. Boston: Harvard Business School Press.

Chua, J. H., Chrisman, J. J., \& Sharma, P. 1999. Defining the family business by behavior. Entrepreneurship Theory and Practice, 23: 19-39.

Cruz, C. C., Gómez-Mejía, L. R., \& Becerra, M. 2010. Perceptions of benevolence and the design of agency contracts: CEO-TMT relationships in family firms. Academy of Management Journal, 53: 69-89.

Cyert, R. M., \& March, J. G. 1963. A behavioral theory of the firm. Englewood Cliffs, NJ: Prentice Hall.

Danneels, E. 2002. The dynamics of product innovation and firm competences. Strategic Management Journal, 23: 1095-1121.

deAngelo, H., \& deAngelo, L. 1985. Managerial ownership of voting rights: A study of public corporations with dual classes of common stock. Journal of Financial Economics, 14: 33-69.

Distelberg, B., \& Sorenson, R. L. 2009. Updating systems concepts in family businesses: A focus on values, resource flows, and adaptability. Family Business Review, 22: 65-81.

Eddleston, K. A. 2008. Commentary: The prequel to family firm culture and stewardship: The leadership perspective of the founder. Entrepreneurship Theory and Practice, 32: 1055-1061.

Eddleston, K. A., \& Kellermanns, F. W. 2007. Destructive and productive family relationships: A stewardship theory perspective. Journal of Business Venturing, 22: 545-565.

Eggers, J. P., \& Kaplan, S. 2009. Cognition and renewal: Comparing CEO and organizational effects on incumbent adaptation to technical change. Organization Science, 20: 461-477.

Eisenhardt, K. M. 1989. Building theories from case study research. Academy of Management Review, 14: 532-550.

Fama, E. F., \& Jensen, M. C. 1983. Separation of ownership and control. Journal of Law and Economics, 26: 301-325.

Farjoun, M. 2010. Beyond dualism: Stability and change as a duality. Academy of Management Review, 35: 202-225.

Feldman, M. S., \& Pentland, B. T. 2003. Reconceptualizing organizational routines as a source of flexibility and change. Administrative Science Quarterly, 48: 94-118.
Finkelstein, S., \& Hambrick, D. C. 1990. Top-managementteam tenure and organizational outcomes: The moderating role of managerial discretion. Administrative Science Quarterly, 35: 484-503.

Finkelstein, S., Hambrick, D. C., \& Cannella, A. A. 2009. Strategic leadership, theory and research on executives, top management teams, and boards. Oxford: Oxford University Press.

Fiss, P. C., \& Zajac, E. J. 2004. The diffusion of ideas over contested terrain: The (non)adoption of a shareholder value orientation among German firms. Administrative Science Quarterly, 49: 501-534.

Ford, J. D., \& Baucus, D. A. 1987. Organizational adaptation to performance downturns: An interpretation-based perspective. Academy of Management Review, 12: 366-380.

Gersick, K. E. 1997. Generation to generation. Boston: Harvard Business School Press.

Gerstner, W.-C., König, A., Enders, A., \& Hambrick, D. C. In press. CEO narcissism, audience engagement, and organizational adoption of technological discontinuities. Administrative Science Quarterly.

Gibson, C. B., \& Birkinshaw, J. 2004. The antecedents, consequences, and mediating role of organizational ambidexterity. Academy of Management Journal, 47: 209-226.

Gilbert, C. G. 2005. Unbundling the structure of inertia: Resource versus routine rigidity. Academy of Management Journal, 48: 741-763.

Gilbert, C. G., \& Bower, J. L. 2002. Disruptive change. When trying harder is part of the problem. Harvard Business Review, 80(5): 94-101.

Gilbert, R. J., \& Newbery, D. M. G. 1984. Uncertain innovation and the persistence of monopoly: Comment. American Economic Review, 74: 238-242.

Gómez-Mejía, L. R., Makri, M., \& Larraza-Kintana, M. 2010. Diversification decisions in family-controlled firms. Journal of Management Studies, 47: 223-252.

Gómez-Mejía, L. R., Núñez-Nickel, M., \& Gutierrez, I. 2001. The role of family ties in agency contracts. Academy of Management Journal, 44: 81-95.

Gómez-Mejía, L. R., Takớcs Haynes, K., Núñez-Nickel, M., Jacobson, K. J. L., \& Moyano-Fuentes, J. 2007. Socioemotional wealth and business risks in family-controlled firms: Evidence from Spanish olive oil mills. Administrative Science Quarterly, 52: 106-137.

Habbershon, T. G., \& Williams, M. L. 1999. A resource-based framework for assessing the strategic advantages of family firms. Family Business Review, 12: 1-25.

Habbershon, T. G., Williams, M. L., \& MacMillan, I. C. 2003. A unified systems theory of family firm performance. Journal of Business Research, 18: 451-465.

Hambrick, D. C., \& Mason, P. A. 1984. Upper echelons: The organization as a reflection of its top managers. Academy of Management Review, 9: 193-206.

Hannan, M. T., \& Freeman, J. 1977. The population ecology of organizations. American Journal of Sociology, 82: 929964. 
Hannan, M. T., \& Freeman, J. 1984. Structural inertia and organizational change. American Sociological Review, 49: $149-164$.

Hatum, A., Pettigrew, A. M., \& Michelini, J. 2010. Building organizational capabilities to adapt under turmoil. Journal of Change Management, 10: 257-274.

Haugh, H. M., \& McKee, L. 2003. "It's just like a family"Shared values in the family firm. Community, Work \& Family, 6: 141-158.

Hill, C. W., \& Rothaermel, F. T. 2003. The performance of incumbent firms in the face of radical technological innovation. Academy of Management Review, 28: 257274.

Hoskisson, R. E., Hitt, M. A., Johnson, R. A., \& Grossman, W. 2002. Conflicting voices: The effects of institutional ownership heterogeneity and internal governance on corporate innovation strategies. Academy of Management Journal, 45: 697-716.

Huff, J. O., Huff, A. S., \& Thomas, H. 1992. Strategic renewal and the interaction of cumulative stress and inertia. Strategic Management Journal, 13: 55-75.

Kaplan, S. 2008. Framing contests: Strategy making under uncertainty. Organization Science, 19: 729-752.

Kaplan, S. 2011. Research in cognition and strategy: Reflections on two decades of progress and a look to the future. Journal of Management Studies, 48: 665-695.

Kaplan, S., Murray, F., \& Henderson, R. M. 2003. Discontinuities and senior management: Assessing the role of recognition in pharmaceutical firm response to biotechnology. Industrial and Corporate Change, 12: 203-233.

Kaplan, S., \& Tripsas, M. 2008. Thinking about technology: Applying a cognitive lens to technical change. Research Policy, 37: 790-805.

Kellermanns, F. W., \& Eddleston, K. A. 2004. Feuding families: When conflict does a family firm good. Entrepreneurship Theory and Practice, 28: 209-228.

Kellermanns, F. W., \& Eddleston, K. A. 2007. A family perspective on when conflict benefits family firm performance. Journal of Business Research, 60: 1048-1057.

Kellermanns, F. W., Eddleston, K., Barnett, T., \& Pearson, A. W. 2008. An exploratory study of family member characteristics and involvement: Effects on entrepreneurial behavior in the family firm. Family Business Review, 21: 1-14.

König, A., Schulte, M., \& Enders, A. 2012. Inertia in response to non-paradigmatic change: The case of meta-organizations. Research Policy, 41: 1325-1343.

Kotter, J. P. 2007. Leading change: Why transformation efforts fail. Harvard Business Review, 85(1): 96-103.

Krippendorff, K. 2004. Content analysis (2nd ed.). Thousand Oaks, CA: Sage.

Lansberg, I. 1999. Succeeding generations. Boston: Harvard Business School Press.

Levitt, B., \& March, J. G. 1988. Organizational learning. Annual Review of Sociology, 14: 319-340.
Lieberman, M. B., \& Montgomery, D. B. 1988. First-mover advantages. Strategic Management Journal, 9(S1): 41-58.

Livengood, R. S., \& Reger, R. K. 2010. That's our turf! Identity domains and competitive dynamics. Academy of Management Review, 35: 48-66.

Loewenstein, G., \& Thaler, R. H. 1989. Anomalies: Intertemporal choice. Journal of Economic Perspectives, 3: 181193.

Lüscher, L. S., \& Lewis, M. W. 2008. Organizational change and managerial sensemaking: Working through paradox. Academy of Management Journal, 51: 221-240.

March, J. G., \& Simon, H. A. 1958. Organizations. New York: Wiley.

McDonald, M. L., Khanna, P., \& Westphal, J. D. 2008. Getting them to think outside the circle: Corporate governance, CEOs' external advice networks, and firm performance. Academy of Management Journal, 51: 453-475.

Milkman, K. L., Chugh, D., \& Bazerman, M. H. 2009. How can decision making be improved? Perspectives on Psychological Science, 4: 379-383.

Miller, D., \& Friesen, P. H. 1980. Momentum and revolution in organizational adaptation. Academy of Management Journal, 23: 591-614.

Miller, D., \& Le Breton-Miller, I. 2005. Management insights from great and struggling family businesses. Long Range Planning, 38: 517-530.

Miller, D., \& Le Breton-Miller, I. 2006. Family governance and firm performance: Agency, stewardship, and capabilities. Family Business Review, 19: 73-87.

Miller, D., Le Breton-Miller, I., \& Lester, R. H. 2010. Family ownership and acquisition behavior in publicly-traded companies. Strategic Management Journal, 31: 201-223.

Miller, D., Le Breton-Miller, I., \& Scholnick, B. 2008. Stewardship vs. stagnation: An empirical comparison of small family and non-family businesses. Journal of Management Studies, 45: 51-78.

Miller, D., Steier, L., \& Le Breton-Miller, I. 2003. Lost in time: Intergenerational succession, change, and failure in family business. Journal of Business Venturing, 18: 513531.

Minichilli, A., Corbetta, G., \& MacMillan, I. C. 2010. Top management teams in family-controlled companies: "Familiness," "faultlines," and their impact on financial performance. Journal of Management Studies, 47: 205222.

Mischel, W. (Ed.). 1977. The interactions of person and situation. Hillsdale, NJ: Lawrence Erlbaum Âssociates.

Mishra, C. S., \& McConaughy, D. L. 1999. Founding family control and capital structure: The risk of loss of control and the aversion of debt. Entrepreneurship Theory and Practice, 23: 53-64.

Mitchell, W. 1989. Whether and when? Probability and timing of incumbents' entry into emerging industrial subfields. Administrative Science Quarterly, 34: 208-230.

Nelson, R. R., \& Winter, S. G. 1982. An evolutionary theory of economic change. Boston: Harvard University Press. 
O'Boyle, E. H., Jr., Pollack, J. M., \& Rutherford, M. W. 2012. Exploring the relation between family involvement and firms' financial performance: A meta-analysis of main and moderator effects. Journal of Business Venturing, 27: $1-18$.

Ocasio, W. 1997. Towards an attention-based view of the firm. Strategic Management Journal, 18: 187-206.

O'Reilly, C. A., \& Tushman, M. L. 2008. Ambidexterity as a dynamic capability: Resolving the innovator's dilemma. Research in Organizational Behavior, 28: 185-206.

Pearson, A. W., Carr, J. C., \& Shaw, J. C. 2008. Toward a theory of familiness: A social capital perspective. Entrepreneurship Theory and Practice, 32: 949-969.

Pfeffer, J. 1992. Managing with power: Politics and influence in organizations. Boston: Harvard University Press.

Pfeffer, J., \& Salancik, G. R. 1978. The external control of organizations. New York: Harper \& Row.

Raisch, S., \& Birkinshaw, J. 2008. Organizational ambidexterity: Antecedents, outcomes, and moderators. Journal of Management, 34: 375-409.

Rumelt, R. 2011. Good strategy, bad strategy. London: Profile Books.

Schulze, W. S., Lubatkin, M. H., \& Dino, R. N. 2003. Exploring the agency consequences of ownership dispersion among the directors of private family firms. Academy of Management Journal, 46: 179-194.

Schulze, W. S., Lubatkin, M. H., Dino, R. N., \& Buchholtz, A. K. 2001. Agency relationships in family firms: Theory and evidence. Organization Science, 12: 99-116.

Sirmon, D. G., Arregle, J. L., Hitt, M. A., \& Webb, J. W. 2008. The role of family influence in firms' strategic responses to threat of imitation. Entrepreneurship Theory and Practice, 32: 979-998.

Sirmon, D. G., \& Hitt, M. A. 2003. Managing resources: Linking unique resources, management, and wealth creation in family firms. Entrepreneurship Theory and Practice, 27: 339-358.

Stafford, K., Duncan, K. A., Dane, S., \& Winter, M. 1999. A research model of sustainable family businesses. Family Business Review, 12: 197-208.

Staw, B. M. 1981. The escalation of commitment to a course of action. Academy of Management Review, 6: 577-587.

Sydow, J., Schreyögg, G., \& Koch, J. 2009. Organizational path dependence: Opening the black box. Academy of Management Review, 34: 689-709.

Szymanski, D. M., Troy, L. C., \& Bharadwaj, S. G. 1995. Order of entry and business performance: An empirical synthesis and reexamination. Journal of Marketing, 59(4): 17-33.
Tagiuri, R., \& Davis, J. 1996. Bivalent attributes of the family firm. Family Business Review, 9: 199-208.

Tan, W.-L., \& Fock, S. T. 2001. Coping with growth transitions: The case of Chinese family businesses in Singapore. Family Business Review, 14: 123-139.

Teece, D. J. 2006. Reflections on "profiting from innovation." Research Policy, 35: 1131-1146.

Thomas, J. B., Clark, S. M., \& Gioia, D. A. 1993. Strategic sensemaking and organizational performance linkages among scanning, interpretation, action, and outcomes. Academy of Management Journal, 36: 239-270.

Tripsas, M., \& Gavetti, G. 2000. Capabilities, cognition and inertia: Evidence from digital imaging. Strategic Management Journal, 21: 1147-1161.

Tushman, M. L., \& Anderson, P. 1986. Technological discontinuities and organizational environments. Administrative Science Quarterly, 31: 439-465.

Tushman, M. L., Newman, W. H., \& Romanelli, E. 1986. Convergence and upheaval: Managing the unsteady pace of organizational evolution. California Management Review, 29(1): 29-44.

Tushman, M. L., \& O’Reilly, C. A. 1996. Ambidextrous organizations: Managing evolutionary and revolutionary change. California Management Review, 36(4): 8-30.

Utterback, J. M., \& Abernathy, W. J. 1975. A dynamic model of process and product innovation. Omega, 3: 639-656.

Vasudeva, G., \& Anand, J. 2011. Unpacking absorptive capacity: A study of knowledge utilization from alliance portfolios. Academy of Management Journal, 54: 611-623.

Weick, K. E. 1998. Introductory essay: Improvisation as a mindset for organizational analysis. Organization Science, 9: 543-555.

Yin, R. K. 2008. Case study research (4th ed.). Thousand Oaks, CA: Sage.

Zachary, M. A., McKenny, A., Short, J. C., \& Payne, G. T. 2011. Family business and market orientation: Construct validation and comparative analysis. Family Business Review, 24: 233-251.

Zahra, S. A. 2010. Harvesting family firms' organizational social capital: A relational perspective. Journal of Management Studies, 47: 345-366.

Zahra, S. A., Hayton, J. C., Neubaum, D. O., Dibrell, C., \& Craig, J. 2008. Culture of family commitment and strategic flexibility: The moderating effect of stewardship. Entrepreneurship Theory and Practice, 32: 1035-1054.

Zellweger, T. M., Kellermanns, F. W., Chrisman, J. J., \& Chua, J. H. 2012. Family control and family firm valuations by family CEOs: The importance of intentions for transgenerational control. Organization Science, 23: 851-868.

Andreas König (andreas.koenig@wiso.uni-erlangen.de) is an assistant professor at the University of Erlangen-Nuremberg, where he also received his Ph.D. in political science. His research focuses on discontinuous innovation and leadership.

Nadine Kammerlander (nadine.kammerlander@unisg.ch) is a research assistant at the Center for Family Business, the University of St. Gallen, and at the Otto-Friedrich- 
University of Bamberg, where she also received her Ph.D. in political science. Her research interests include family businesses and organizational adaptation.

Albrecht Enders (albrecht.enders@imd.ch) is a professor of strategy and innovation at IMD. He holds a Ph.D. in strategic management from the Leipzig Graduate School of Management. His major interest is the response of organizations to radical changes in their environment. 